\title{
In the name of science
}

\author{
The role of biologists in Nazi atrocities: lessons for today's scientists
}

Racial prejudice is as old as mankind. It is one of the dark sides of man that we tend to decrease the value of others in order to raise ourselves. And at some point in history, prejudice found a faithful servant in science. Scientific theories and

\section{Scientific theories and}

arguments were used to support

the inferiority of other races

arguments were used to support the inferiority of other races, thereby legitimising crimes committed throughout history and all over the world. They were used in the United States to justify slavery and the Indian wars, as well as later for the sterlisation of disabled people. The emergence of eugenics as an 'applied science' culminated in the horrendous atrocities committed by the Nazis during the Third Reich. Society was to be cleaned of all alien contamination, hence the German phrase 'Rassenhygiene' meaning 'racial hygiene'. Jews, gypsies, homosexuals and people with hereditary diseases were deprived of their human rights, herded into concentration camps, used for scientific experimentation and murdered. And the scientists who provided the scientific backing were respected university professors or researchers of the Kaiser Wilhelm Society (KWS), the predecessor of the Max Planck Society. Many of them remained in renowned positions even after 1945, influential enough to delay an unbiased historical confrontation.

The Max Planck Society is currently engaged in coming to terms with its past. Its president, Hubert Markl, launched a research programme, History of the Kaiser Wilhelm Society in the National Socialist Era, in 1999 to investigate the involvement of scientists of the KWS in Nazi crimes. First results have now been published (Proctor, 2000; Sachse and Massin, 2000; Schmuhl, 2000). In June 2001, Markl acknowledged the historical responsibility of the Max Planck Society at a scientific symposium entitled 'Biomedical Sciences and Human Experimentation at the Kaiser Wilhelm Institutes-The Auschwitz Connection', which was held in conjunction with the historical research programme. In his opening speech he said, 'We must be prepared as well-no matter how painful it may be, and even precisely because it hurts-to accept the truth and face up to our responsibility to learn for the present and the future from the insight into the past'.

Discrimination based on science has a long history. In the 19th century, scientists, mainly from the USA, became interested in craniometry, the determination of intelligence through skull measurements. Between 1830 and 1850, Samuel George Morton collected over 1000 skulls to determine an 'objective' racial ranking according to physical characteristics such as brain size. Using these data, Morton declared that individual races ranked according to his preconceptions: whites first, then native Americans and black people last. Later, Stephen Jay Gould reinvestigated the data and found Morton's summaries to be 'a patchwork of fudging and finagling in the clear interest of controlling a priori convictions'. Yet Gould would not accuse Morton of conscious fraud: 'All I can discern is an a priori conviction about racial ranking so powerful that it directed his tabulations along pre-established lines' (Gould, 1981). Morton was succeeded in this area of study by Francis Galton, Robert Bennett Bean and Paul Broca, to name but a few, who measured the relationship between brain parts, brain weight or cranial folds, discarding one criteria and turning their attention to another to justify

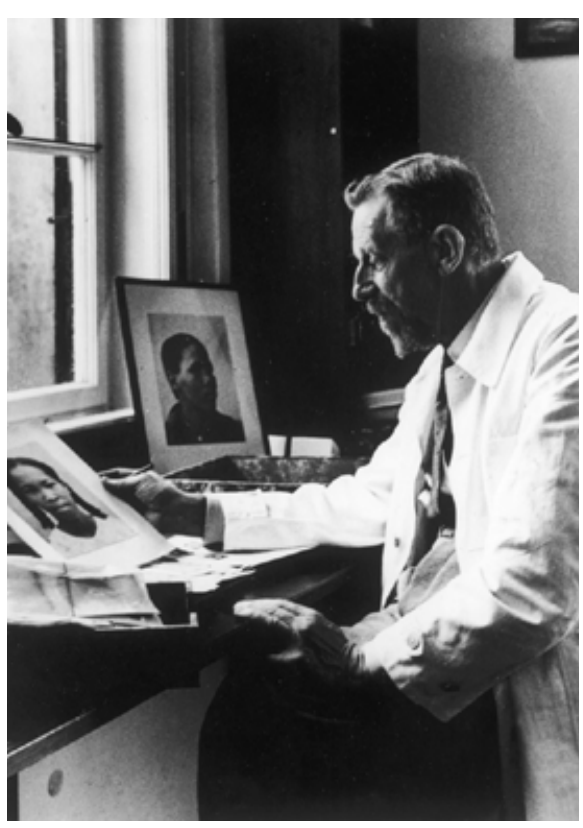

Eugen Fischer (1874-1967). Courtesy of the Archiv zur Geschichte der Max-Planck-Gesellschaft, Berlin-Dahlem.

their prejudices accordingly (Gould, 1981).

It was Galton who first coined the word eugenics as the study of agencies under social control that may improve or impair the racial qualities of future generations'. In Hereditary Character and Talent, he wrote, 'If a twentieth part of the cost and pains were spent in measures for the improvement of the human race that is spent on the improvement of the breed of horses and cattle, what galaxy of genius might we not create!'. The eugenics movement predicted the degeneration of modern civilisation, in part due to 'differential reproduction', and proffered scientific arguments and scientific means to counteract this. The theory of eugenics quickly spread world-wide, but the 


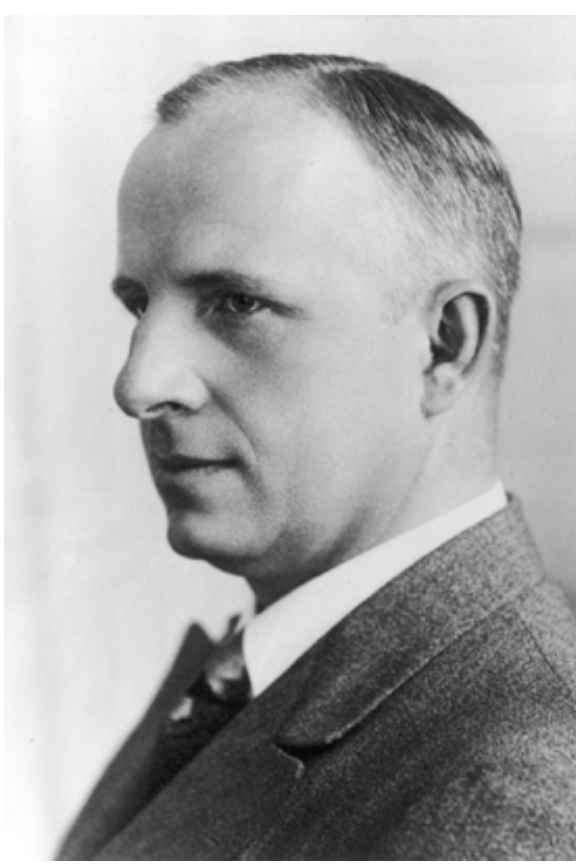

Otmar von Verschuer (1896-1969). Courtesy of the Archiv zur Geschichte der Max-Planck-Gesellschaft, Berlin-Dahlem.

degree to which it was implemented varied from country to country. Even under social democratic governments, atrocities took place. In Sweden, for example, 63000 people-including most resident gypsies-were legally sterilised between 1934 and 1975, mainly because of 'antisocial behaviour'.

In Germany, eugenics gained many supporters long before Hitler came to power, and was not solely a monstrosity of Hitler as so often portrayed. German scientists contributed considerably to the rise of eugenics. At the beginning of the 1920s, Erwin Baur, Eugen Fischer and Fritz Lenz published Human Heredity Teaching and Racial Hygiene, a textbook of major impact with multiple subsequent editions. In 1927, Fischer was appointed Director of the newly-founded Kaiser Wilhelm Institute (KWI) for Anthropology, Human Genetics and Eugenics in BerlinDahlem, where Lenz joined him in 1934. The book ascended to become the standard text for substantiation of National Socialist ideology and Lenz prided himself on the fact that parts of it were reflected in Hitler's speeches (Müller-Hill, 1981).

Ernst Rüdin was another scientist instrumental in setting the framework for racial politics. In 1905 he co-founded the
'Society for Racial Hygiene' to promote eugenics, and by 1931 he was the Director of the Deutsche Forschungsanstalt (DFA)/KWI for Psychiatry in Munich, where his interests in the psychiatric aspects of population genetics strongly influenced the general orientation of the institute.

From 1910 onwards, Fischer, Lenz and Rüdin propagated the political applications of their research. A sterilisation rule drafted by Fischer and Lenz was proclaimed as the 'law for the prevention of progeny with hereditary defects' in 1933, shortly after Hitler came to power. 'The importance of racial hygiene has only become known to all intelligent Germans through the political work of Adolph Hitler, and it was only through him that our more than thirty-year-old dream has become reality and racial hygiene principles have been translated into action', Rüdin said.

Indeed, the interaction between science and politics during the National Socialist era was manifold. Many scientists were on expert advisory committees, directly feeding the system with scientific justification, many of them scientists from the KWS. Through them, the violent antiSemitism was claimed to have scientific backing. Rüdin and Lenz were both members of the 'Expert Committee for Population and Race Politics' of the Ministry of the Interior. Thanks to Rüdin's radical suggestions, the indications for compulsory sterilisation were extended to 'morally feeble and other psychopaths'. The council furthermore developed regulations that paved the way for the 'law for the protection of German blood and German honour' in 1935, the infamous Nuremberg Law, prohibiting marriage and extramarital intercourse between Jews and German citizens. Otmar von Verschuer, Fischer's successor as Director of the KWI for Anthropology, Human Genetics and Eugenics stated, 'It is important that our race politics-also in the Jewish question-get an objective, scientific background, which is also acknowledged in broader circles'.

Scientists were then required to put Nazi ideology into practice. The Nuremberg Law required the classification of all Germans as 'Aryans', 'Full' 'Half' or 'Quarter Jew'. In cases of doubt, the Reich Kinship Bureau consulted scientists, many of whom were from the KWI for Anthropology, Human Genetics and Eugenics.
Their judgement decided the fate of these people, and decisions were taken with scientific precision. Never did they fake

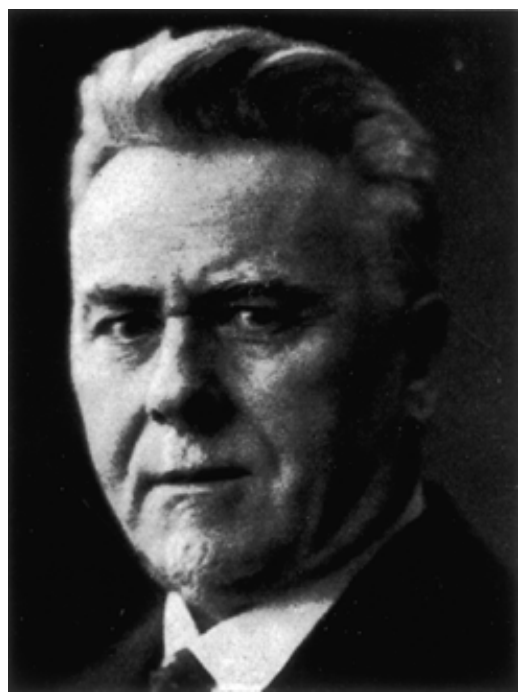

Ernst Rüdin (1874-1952). Courtesy of the Archiv zur Geschichte der Max-Planck-Gesellschaft, Berlin-Dahlem.

an expert report to save someone's life. Wolfgang Abel, a scientist at the KWI proudly gloated in an interview: 'I had become the expert in the field of human facial and cranial shape because of my genetical studies-just as the Norwegian, Dr Quelprud, in our institute was the expert in the inheritance of the shape of the ear' (Müller-Hill, 1984). Scientists

\section{Scientists were so devoted to their peculiar field of research to ever reflect the consequences of their deeds}

were too devoted to their peculiar field of research to ever reflect on its consequences.

Just as anthropologists reigned over the lives of despised races, it was the psychiatrists who decided the fate of people with neuropsychiatric indications. To fulfil this task, psychiatrists were trained at the DFA/KWI for Psychiatry in courses organised by its director Rüdin. James Watson later dubbed it 'elimination by scientific selection'.

Science also directly profited from the system since these people deprived of their human rights were used for experiments. Research projects were 


\section{analysis}

followed that strongly depended on the political system being so contemptuous of

Euthanasia movement. 'You kill them anyway; at least take out the brains so the

\section{Just as anthropologists reigned over the lives of despised races, it was the psychiatrists who decided the fate of people with neuropsychiatric indications}

human beings, and on its murderous euthanasia programme. In a research proposal to the Reich Research Council, Rüdin wrote: '[...] what is important to safely and humanly antagonise counterselective forces in the German society would be to research the question: which children can, already as children, be undoubtedly characterised as inferior and worth eliminating, so that they can be suggested for euthanasia'. With this goal, Rüdin initiated a collaboration with the University Hospital in Heidelberg, where Carl Schneider was conducting experiments to differentiate between inherited and acquired mental retardation. The patients, mainly children, were subjected to a series of examinations to investigate their learning abilities, and results were compared with the pathology of their brains after their murder.

This was only one of many research

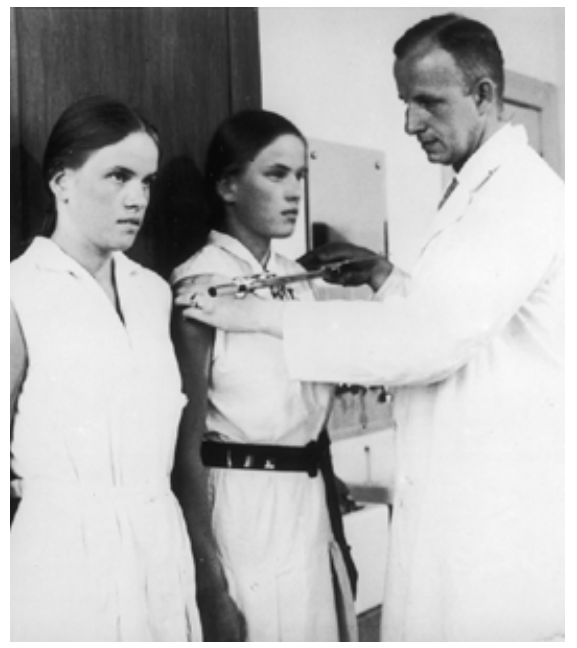

Otmar von Verschuer measuring twins. Courtesy of the Archiv zur Geschichte der Max-PlanckGesellschaft, Berlin-Dahlem.

projects in the field of brain research. Julius Hallervorden, head of the department of histopathology at the KWI for Brain Research in Berlin-Buch, took the initiative to co-operate with the material can be used', he said. The brain research community had developed a close network of collaborations between research institutes and psychiatric wards so efficient that the scientists were supplied with an excess of brain material. At least 194 brains were analysed in the DFA/KWI for Psychiatric Research while some 300 to 400 brains from euthanasia victims were appropriated by the KWI for Brain Research.

The history of the KWI for Anthropology, Human Genetics and Eugenics, the KWI for Psychiatry and the KWI for Brain Research has been investigated since the middle of the 1990s. Thorough research of the involvement of the KWI for Biochemistry has only recently begun through the aforementioned research programme. Of specific interest for the selfassessment of the Max Planck Society is the role of Adolf Butenandt, who won the Nobel Prize in 1939 for his work on sex hormones. From 1936 onwards, he was Director of the KWI for Biochemistry in Berlin-Dahlem, later in Tübingen, and he retained this position after the Institute was continued as the Max Planck Institute in 1949. In 1960, Butenandt became President of the Max Planck Society, a post he held until 1972.

The KWI for Biochemistry collaborated on projects with The KWI for Anthropology, Human Genetics and Eugenics. The Directors of the two Institutes, Verschuer and Butenandt, shared common interests in the field of inherited diseases and inherited susceptibility to infectious diseases. Gerhard Ruhenstroh-Bauer at the KWI for Biochemistry and Hans Nachtheim at the KWI for Anthropology, Human Genetics and Eugenics conducted a research programme to distinguish inherited and acquired epilepsy. It was assumed that oxygen deprivation in the brain through reduction of air pressure would induce an earlier epileptic attack in cases of inherited epilepsy compared with those with acquired epilepsy. Six children of the Landesanstalt Branden-
burg-Görden were used for experiments in the vacuum chamber of the Air Force base at Rechlin in 1943. RuhenstrohBauer later claimed not to have known that these children were threatened with euthanasia. Although none of the children was in fact harmed in the experiments, the health of the children was certainly placed at risk for 'scientific progress'.

In a different set of experiments, Verschuer and Günther Hillmann at the KWI for Biochemistry investigated the inheritance of differential susceptibility to infectious diseases. Specific proteins in the bloodstream were thought to be responsible for racial differences in the susceptibility to such diseases. Hillmann was recruited to the project because of his biochemical expertise, to isolate the substances from the blood with the eventual goal of synthesising them as a treatment. Butenandt had already moved to the institute's new location, Tübingen, but he kept very good contact with Hillmann and Verschuer and was very enthusiastic about the project. Between the summer and autumn of 1944, Josef Mengele, Verschuer's former assistant and then camp doctor in Auschwitz, instructed his Jewish slave assistant Miklos Nyiszli to send research material to the KWI for Anthropology, Human Genetics and Eugenics: eyes from murdered gypsies, internal organs, skeletons and blood samples. It is most likely that the blood samples included those of twins, one of them deliberately infected with typhus or tuberculosis by Mengele for Verschuer's experiments. It is not clear to what extent Butenandt was informed about the criminal background of the experiments. But even once it became public in 1946, Butenandt did not distance himself from Verschuer, nor did he show any sign of regret.

After the war, the Allies viewed Butenandt as innocent enough to allow him to keep his position in Tübingen. Verschuer, in contrast, had fallen into disrepute because of his connection to Mengele and because his request for a 'total solution of the Jewish question'meaning the mass murders of Jews in the gas chambers of Auschwitz and Treblinka-became public. It was Butenandt who played a major role in his rehabilitation by writing a document, together with Boris Rajewski, Max Hartmann and Wolfgang Heubner in 1946, 'one of the 


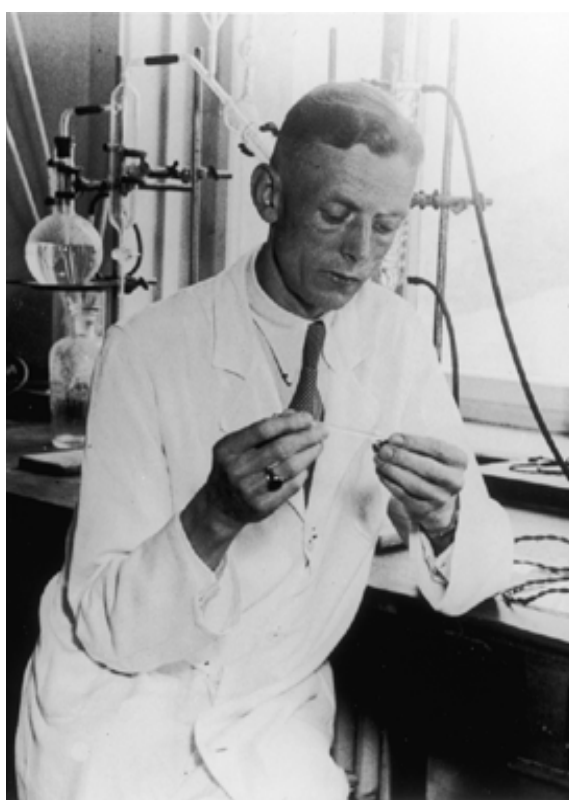

Adolf Butenandt (1903-1995). Courtesy of the Archiv zur Geschichte der Max-Planck-Gesellschaft, Berlin-Dahlem.

most astonishing examples of a Persil-certificate-literature in the post war period' (Proctor, 2000) [Persil-certificate, German: Persilschein, named after the washing powder 'Persil', as it certified the cleanliness of the person in questionEd.] The authors were ready for any manipulation of the truth to prove Verschuer's innocence. They claimed that Verschuer was not aware of any criminal background to his experiments, and even went as far as doubting that Mengele was conscious of it. This document achieved Verschuer's rehabilitation and even secured him a position as Professor for Human Genetics at the University in Münster.

Butenandt was not anti-Semitic. Unlike Verschuer or Rüdin, he never expressed strong discriminating ideas or became directly involved in political advice. Butenandt was simply enthusiastic about science, an obsession that overrode any social responsibility. After the war, in conjunction with his involvement in the rehabilitation of his peers, he promoted the view that pure science was beyond any political involvement and that real scientists could not possibly have been Nazis. Also Verschuer was worried that the reputation of his science would suffer from a critical review after the war. In his defence, he liked to differentiate between 'pseudo-scientific race teaching' and 'scientific anthropology'. Any criticism of science during the National Socialist era could only be accusing pseudo-science, which was not real science, but 'politics' or 'literature', as he put it. Of course, in his view, his own research was always pure science.

Even today, we prefer to perceive the Nazi era as a period of 'pseudo-science'. But this is dangerous, as it would relieve scientists from any responsibility for the crimes committed. 'Criminal acts of this kind are an inexcusable shame, not only

It was scientific and medical methods, scientific and medical speech that were used in carrying out these crimes in the name of science

for those who prepared them, but also for all those who tolerated them, in fact for the life sciences themselves, in the name of which they were committed', Markl said in his speech. '[Mengele] corresponded with them [scientists at the $\mathrm{KWI}$ in the language of medicine, and this language requires precision and realism', says Jona Laks, head of the 'Organization Mengele Twins', and a Mengele victim herself (Laks, 2001). It was scientific and medical methods, scientific and medical speech that were used in carrying out these crimes in the name of science. Clearly, the scientific value of an experiment is not tainted by the experiment being carried out on murder victims. 'It would be wrong to condemn them as bad experiments, if they were carried out on mice', writes Benno Müller-Hill, Professor of Genetics at the University of Cologne, referring to the experiments by Verschuer and Hallervorden (1984).

With the sequencing of the human genome, scientists will gain a better understanding of our genes and will eventually announce the truth-the pure truth this time, so they think. Possibly they will find no genetic predispositions to traits such as intelligence, anti-social behaviour or aggression, or possibly scientists will find them not identifiable because these characteristics are simply not measurable. 'You can't tell from looking at the human genome who is who other than who is male or female', J. Craig Venter said at a speech in Birmingham in 2000. But if such predispositions are postulated, there is a danger of human beings being stigma- tised due to their genetic background. It is a valid prediction that the inheritance of mental traits will be postulated to be linked to genes. It is also a valid prediction that a differential distribution of genes among different races will be determined. Looking at the past, the inheritance of these traits has been viewed as scientific proof many times, and each time the proof was later unmasked as misinterpretation. One might question how close to the real truth one will ever get, no matter how much the scientists promise to have found it this time.

But in the case where someone postulates a genetic predisposition among a certain ethnic group, we must be aware that the description of any difference does not entail a racist conclusion. 'From a scientific point of view, it should be possible to make the statement that ethnic groups are genetically different in such genes, if there is hard proof that they are different. For me, racism begins when it is claimed that genetically different groups may be stigmatized and should not have equal rights', Müller-Hill wrote (1997). 'Science determines truths, not values'. But this truth is always brought to us through the interpretation of scientists. In the past it was scientists who interpreted racial differences as the justification to murder. 'Also high lead-edge research is not invulnerable to moral abysses', says Markl. It is the responsibility of today's scientists to prevent this from happening again.

\section{References}

Gould, S.J. (1981) The Mismeasure of Man. W.W. Norton \& Company, NY.

Müller-Hill, B. (1981) 'Die Philosophen und das Lebendige' Campus, Frankfurt, Germany.

Müller-Hill, B. (1984) Tödliche Wissenschaft (English translation by George R. Fraser: Murderous Science, 1998). Cold Spring Harbor Laboratory Press, Cold Spring Harbor, NY.

Müller-Hill, B. (1997) The Specter of Kakogenics. The Genetical Society, 33, 13-14.

Proctor, R.N. (2000) 'Adolf Butenandt (19031995). Nobelpreisträger, Nationalsozialist und MPG-Präsident. Ein erster Blick in den Nachlass.' http://www.mpiwg-berlin.mpg.de/ $\mathrm{kwg} /$ publications.htm\#Ergebnisse

Sachse, C. and Massin, B. (2000) 'Biowissenschaftliche Forschung an KaiserWilhelm-Instituten und die Verbrechen des NS-Regimes. Informationen über den gegenwätigen Wissensstand.' http:// www.mpiwg-berlin.mpg.de/kwg/publications. htm\#Ergebnisse 
Schmuhl, H.-W. (2000) 'Hirnforschung und Krankenmord. Das Kaiser-Wilhelm-Institut für Hirnforschung 1937-1945.' http://www .mpiwgberlin.mpg.de/kwg/publications.htm\#Ergebnisse
Watson, J.D. (1998) Five days in Berlin. Afterword to Müller-Hill,. Murderous Science. Cold Spring Harbor Laboratory Press, Cold Spring Harbor, NY.
Katrin Weigmann

DOI: $10.1093 / \mathrm{embo-reports/kve217}$

\title{
Tackling the most difficult diseases
}

\author{
Genetics and genomics open new strategies to fight vector-borne diseases
}

The 1990s witnessed one of the most successful programmes to eradicate malaria by tackling its vector, the Anopheles mosquito. Its main component was the release of sterilised male mosquitoes into the environment, which competed with wild ones for the available females. By repeating this every year with everincreasing numbers of sterilised flies, health officials from the World Health Organization (WHO) and various countries hoped to eradicate the mosquito and thus malaria. In some parts of the world, this method indeed worked; southern Europe and large areas of Asia, North and Central America and Africa became virtually malaria free. But while Europe has remained so, the mosquitoes and the diseases they transmit have come back with a vengeance in many areas around the world.

The latest data released in August 2001 show that there are now between 700000 and 2.7 million deaths each year from malaria, $75 \%$ of which are African children. According to the Multilateral Initiative on Malaria, this is a higher mortality rate than the yearly toll of AIDS in Africa. Besides the fatalities, between 400 and 900 million acute episodes of fever occur in children under the age of five which can slow brain development and retard cognitive abilities. Anthony James, a geneticist at the University of California in Irvine, refers to malaria as 'the most difficult vector-borne disease to control'.

Controversy abounds in the scientific community about the causes of the resurgence of these and other vector-borne infectious diseases such as leishmaniasis, yellow fever, encephalitis and dengue fever. Theories vary from global warming to the discontinuation of the use of DDT, but as Paul Reiter from the Centers for Disease Control in Atlanta, Georgia,

remarked 'Public concern should focus on ways to deal with the realities of malaria transmission, rather than on the weather'.

A number of scientists are responding to Reiter's challenge by focusing on genetics in order to analyse and ultimately modify the parasites or their vectors. 'Genetic engineering complements the other modalities of improved public health care and vaccine, drug and pesticide development, and is not aimed at replacing them', said Bruce Christensen, chair of the Department of Animal Health and Biomedical Sciences at the University of Wisconsin in Madison. 'It is unlikely that any single strategy will be successful for the complete control of malaria', James agrees. 'We anticipate that an integrated approach that includes bed nets,

Genetic engineering complements other modalities of improved public health care and vaccine, drug and pesticide development

parasite-resistant mosquitoes and vaccines will ultimately control or eliminate the disease if the role of each component intervention method is optimised for a specific region of transmission', he said.

Indeed, developing vaccines against the protozoan causing malaria and leishmaniasis has been extremely challenging, because the pathogens have developed various ways to evade the patient's immune system. But a number of groups are finally making headway. Giampetro Corradin of the University of Lausanne in Switzerland recently stated that his synthetic malaria vaccine, derived from a surface protein of the Plasmodium falciparum parasite, was the first to produce both strong B- and T-cell responses in early-stage human testing. Corradin plans to vary the peptide sequence in order to make the vaccine effective against several strains of the organism.

Another group is investigating the ability of $P$. falciparum to suppress an immune response, also with the goal of developing a vaccine against malaria. Magdalena Plebanski of the Austin Research Institute in Melbourne, Australia discovered that Plasmodium uses an 'altered peptide ligand' (APL) antagonism to dampen the cell-mediated immune response. It specifically disarms the protective $T$ cells that ordinarily would kill infected cells. Plebanski's team has produced synthetic APLs that are agonists for T-cell activation, counteracting the antagonistic APL peptide variants found in Plasmodium. Mice infected with a mouse version of malaria that had been stimulated with two 